\title{
Clinical Experience with Adjunctive Lacosamide in Adult Patients with Focal Seizures
}

\author{
Fokal nöbetli Hastalarda Lakosamid Ek Tedavisi \\ İle İlgili Klinik Deneyimler
}

\author{
Demet İLHAN ALGIN, Oğuz Osman ERDiNÇ, Gönül AKDAĞ
}

Department of Medical Faculty, Eskisehir Osmangazi University Faculty of Medicine, Eskişehir, Turkey

\section{Summary}

Objectives: The aim of this study was to report first clinical experience in Turkey using lacosamide (LCM) as adjunctive therapy in patients with focal onset seizure.

Methods: Total of 128 adult patients with focal seizures (67 males and 61 females) were included in the study. Thirteen of 128 patients were withdrawn from the study due to adverse events. In all, 22 of the patients used combination of 4 antiepileptic drugs (AEDs), 36 used 3 AEDs, 34 used 2 AEDs, and 28 used 1 AED. Seizure frequency and severity were evaluated according to patient diaries and history. Treatment response to LCM was determined by assessing change in seizure frequency after 6 months of LCM therapy. Responders were defined as patients who achieved seizure frequency reduction of $\geq 50 \%$.

Results: Mean age of the patients was 29.2 years (range: 18-53 years). After 6 months of LCM therapy, 49 patients (42.6\%) had achieved reduction in seizure frequency, with complete seizure suppression reported in $18.2 \%$ of patients $(n=21)$. Response rate was $<50 \%$ in 29 patients, and 19 patients did not respond to treatment. After use of LCM, 70 patients (60.9\%) were categorized as responders and 45 (39.1\%) were non-responders. Starting dose of LCM was $100 \mathrm{mg} /$ day and was increased up to $600 \mathrm{mg} /$ day as necessary (mean: $335 \pm 28.2 \mathrm{mg} / \mathrm{day}$ ). Adverse effects occurred in 22 patients (17.2\%).

Conclusion: These data suggest that LCM is an effective add-on antiepileptic drug for focal epilepsy patients.

Keywords: Epilepsy; lacosamide; therapy.

\section{Özet}

Amaç: Bu çalışmada fokal başlangıçlı nöbetleri olan hastalarda lakosamid (LCM) ek tedavisi ile ilgili ilk deneyimlerimizi bildirmeyi amaçladık. Gereç ve Yöntem: Fokal nöbetleri olan toplam 128 erişkin hasta (67 erkek ve 61 kadın) çalışmaya alındı. Yüz yirmi sekiz hastadan 13 hasta yan etkilerden dolayı çalışmadan dışlandı. Yirmi iki hasta dörtlü antiepileptik ilaç (AEI), 36 hasta üçlü AEI, 34 hasta ikili AEI, 28 hasta bir AEI almaktaydı. Nöbet sıklığı ve şiddeti hasta günlükleri ve öykülerine göre değerlendirildi. Lakosamid tedavisine cevap LCM tedavisi başlandıktan altı ay sonra nöbet sıklığında değişikliğe göre tanımlandı. Nöbet sıklığında $\geq \% 50$ azalma tedaviye yanıt olarak değerlendirildi.

Bulgular: Hastaların yaş ortalaması 29.2 (dağılım, 18-53) yıl idi. Lakosamid tedavisi başlandıktan altı ay sonra 49 (\%42.6) hastada nöbet sıklığında azalma, 21 (\%18.2) hastada tam nöbet kontrolü sağlandı. Yirmi dokuz hastada nöbet sıklığında <\%50 azalma saptanırken, 19 hasta tedaviye yanıt vermedi. Lakosamid tedavisi sonrası 70 hasta (\%60.9) tedaviye yanıt veren, 45 (\%39.1) hasta tedaviye yanıtsız olarak değerlendirildi. Lakosamid 100 mg/gün başlandı ve gereklilik durumuna göre 600 mg/gün (ortalama 335 28.2 mg/gün) olarak artırıldı.

Sonuç: Bizim bulgularımız LCM ek tedavisinin fokal epilepsili hastalarda etkin olduğunu gösterdi.

Anahtar sözcükler: Epilepsi; lakosamid; tedavi.

Submitted (Geliş): 19.01.2017 


\section{Introduction}

Epilepsy is one of the most common neurological disorders, affecting up to $2 \%$ of the population worldwide. ${ }^{[1]}$ Treatment of epilepsy often imposes an exposure to various antiepileptic drugs (AEDs) and requires long-term commitment and compliance from the patient. ${ }^{[2]}$ While there is small percentage of people who undergo successful epilepsy surgery, the vast majority of patients are maintained with chronic medical management. Despite the advent of new AEDs over the past 15 years, 30\% of epilepsy patients still experience recurrent seizures and many experience undesirable side effects. ${ }^{[3,4]}$ Therefore, there are still unmet needs for the treatment of epilepsy and there remains a need to develop new AEDs that can reduce seizure frequency and severity as well as improve safety and tolerability.

Epidemiological research has demonstrated that prevalence of epilepsy is higher in developing countries, with incidence rate of as high as 18.5 per population of $1,000 .{ }^{[5,6]}$ Various epidemiological reports are available from diverse regions of Turkey citing active prevalence rate of 5 to 8.5 per $1,000 .{ }^{[7,8]}$ Adjunctive therapy with AEDs is optimal treatment for patients with refractory epilepsy. LCM was approved for adjunctive treatment for focal onset seizures in patients aged $\geq 16$ years by the European Medicines Agency (August 2008) and in patients aged $\geq 17$ years by the US Food and Drug Administration (October 2008). ${ }^{[9]}$

LCM selectively enhances slow inactivation state of voltagegated sodium channels (VGSCs) and increases proportion of channels entering the slow inactivation state. This results in stabilization of neuronal membranes and inhibition of sustained repetitive neuronal firing. Unlike other antiepileptics, including carbamazepine (CBZ), felbamate, lamotrigine (LTG), oxcarbazepine (OXC), phenytoin (PHT), and topiramate (TPM), LCM does not alter fast inactivation of VGSCs.

In preclinical experiments, LCM has also been shown to bind to collapsin response mediator protein 2 (CRMP-2), which is involved in neuronal differentiation, regulation of gene expression, polarization, and axonal outgrowth. The role of CRMP-2 binding in seizure control is unknown at this time, but it may be a factor in the disease-modifying potential of LCM..$^{[9,10]}$

Recommended initial dose of LCM in adults is $50 \mathrm{mg}$ ad- ministered twice daily, with weekly titration in $100 \mathrm{mg} /$ day increments. Usual maintenance dose for adults is 200 to 400 $\mathrm{mg} /$ day. In clinical trials, increasing daily dose to $600 \mathrm{mg}$ did not provide greater seizure control, but was associated with higher incidence of adverse effects. ${ }^{[10]}$

LCM was approved in Turkey in October 2012 and was added to the government insurance reimbursement system in September 2014. The present study was an assessment of the efficiency and safety of LCM in 128 patients with focal onset seizures, with or without secondary generalization.

\section{Materials and Methods}

Results of use of LCM in 128 patients with epilepsy with different etiologies who were admitted to our clinic were evaluated retrospectively. Gender, age, electroencephalography findings, seizure types, electrocardiogram results, routine laboratory findings, seizure frequency before and after LCM use, other AEDs taken with LCM, dose of LCM, duration of LCM administration, and adverse effects of LCM (if seen) were evaluated. CBZ, PHT, OXC, LTG, TPM, clobazam $(C L B)$, levetiracetam (LEV), phenobarbital (PB), pregabalin $(\mathrm{PGB})$, valproate (VPA) and zonisamide (ZNS) were the drugs used as polytherapy in different combinations. LCM was initiated at total of $100 \mathrm{mg} /$ day, administered in 2 doses. Maximum dose of LCM administered was $600 \mathrm{mg} /$ day, delivered in 2 equal doses. Patients were monitored once a month for the first 3 months of treatment, with subsequent follow-up periods of 1 to 3 months, depending on the frequency of seizures. Patients were considered seizure-free if they did not have seizures 6 months after starting LCM treatment.

Patients were divided into 4 categories according to the level of response to treatment: complete seizure control (Group A), $\geq 50 \%$ reduction in seizure frequency (Group B), $<50 \%$ reduction in seizure frequency (Group C), and no change in seizure frequency (Group D). Efficiency of LCM was determined by the patients' diaries. If seizure frequency decreased $\geq 50 \%$, it was accepted as positive response to treatment.

The Eskişehir Osmangazi University of Medicine ethics committee approved this study and all participants provided written, informed consent in accordance with the Declaration of Helsinki.

\section{Statistical analysis}

Comparisons were made using Student's t-test, Mann-Whit- 
ney $U$ test or chi-square test, as appropriate. Logistic regression analysis was applied to identify potential predictors of seizure freedom; associations with an outcome that were biologically plausible were identified for statistical analysis. Results were considered significant with $p$ value $<0.05$.

\section{Results}

Total of 128 adult patients with partial seizures were included in the study. Of those, 13 patients stopped the treatment due to adverse events.

Of the 115 patients with epilepsy receiving LCM, 55 (47.9\%) were female and 60 (52.1\%) were male. Mean age of the patients was 29.2 years (range: $18-53$ years). Patients used LCM for minimum of 6 months and maximum of 26 months (mean: 11.8 months) during follow-up.

Seizures were etiologically classified according to the 2010 Revised Classification of Seizures and Epilepsy published by the International League Against Epilepsy: ${ }^{[11]}$ genetic and/ or inherited, structural/metabolic, or unknown (Table 1).

Of 115 patients, etiology was determined to be genetic in 8 patients (6.9\%), structural/metabolic in $79(68.7 \%)$, and of unknown origin in 28 (24.4\%). Epilepsy of structural/metabolic origin was due to perinatal pathology (25.9\%), hippocampal sclerosis and temporal gliosis (16.9\%), malformation of cortical development (16.6\%), cerebrovascular disease (15.9\%), other cerebral malformation (14.8\%), central nervous system infection (12.3\%), neuroectodermal disorder
(6.1\%), and presumed autoimmune disease (2.4\%). Genetic and/or inherited etiology in 8 patients was Lennox-Gastaut syndrome in 3 cases, Rett syndrome in 2 cases, myoclonic epilepsy with ragged-red fibers in 2 cases, and Dandy-Walker syndrome in 1 case.

Initial dose of LCM was $100 \mathrm{mg} /$ day and was increased up to $600 \mathrm{mg} /$ day if necessary (mean: $335 \pm 28.2 \mathrm{mg} /$ day). Dose was increased to $600 \mathrm{mg} /$ day in 6 patients; no difference in adverse events was observed.

Seizure frequency and severity were reduced $\geq 50 \%$ in 49 patients $(42.7 \%)$ and $<50 \%$ in 26 patients (22.7\%). Twentyone patients (18.2\%) reported complete seizure freedom. Nineteen patients (15.6\%) did not respond to treatment (Table 1).

The patients were grouped according to their response to LCM as follows: non-responders (if seizure frequency was reduced $<50 \%$ ) or responders (if seizure frequency was reduced $\geq 50 \%$ ). After LCM therapy, 70 patients (60.9\%) were found to be responders and 45 (39.1\%) were non-responders (Table 1).

Of the 115 patients, 19 (16.5\%) received LCM as first AED, $32(27.8 \%)$ as second, $36(31.4 \%)$ as third, and $28(24.3 \%)$ as fourth add-on AED (Table 1).

Among the 70 responders, 54 (77.1\%) had structural/metabolic etiology, and 16 (22.9\%) had unknown etiology. Of 45

Table 1. Clinical features of the 115 patients

\begin{tabular}{|c|c|c|c|c|}
\hline & Seizure free & $\geq 50 \%$ reduction & $<50 \%$ reduction & Non responder \\
\hline Age (year) (min-max) & $28.18(18-31)$ & $30.2(19-32)$ & $33.7(19-35)$ & $25.2(18-28)$ \\
\hline \multicolumn{5}{|l|}{ Gender, n (\%) } \\
\hline Male $(n=60)$ & $9(7.9)$ & $27(23.5)$ & $14(12.1)$ & $10(8.7)$ \\
\hline Female $(n=55)$ & $12(10.4)$ & $22(19.1)$ & $12(10.4)$ & $9(7.9)$ \\
\hline \multicolumn{5}{|l|}{ Etiology (n=115), n (\%) } \\
\hline Genetic $(n=8)$ & - & - & $5(4.3)$ & $3(2.6)$ \\
\hline Structural/metabolic $(n=79)$ & $17(14.8)$ & $37(32.1)$ & $12(10.4)$ & $13(11.3)$ \\
\hline Unknown $(n=28)$ & $4(3.5)$ & $12(10.4)$ & 9 (7.8.) & $3(2.6)$ \\
\hline \multicolumn{5}{|l|}{ Concomitant drugs ( $n=115), n(\%)$} \\
\hline First drug $(n=19)$ & $10(8.7)$ & $7(6.1)$ & $2(1.7)$ & - \\
\hline Second drug $(n=32)$ & $7(6.1)$ & $21(18.3)$ & $4(3.5)$ & - \\
\hline Third drug $(n=36)$ & $4(3.5)$ & $14(12.2)$ & $12(10.4)$ & $7(5.2)$ \\
\hline Fourth drug $(n=28)$ & - & $7(6.1)$ & $9(7.8)$ & $12(10.4)$ \\
\hline All cases & $21(18.2)$ & $49(42.6)$ & $26(22.7)$ & $19(16.5)$ \\
\hline
\end{tabular}


Table 2. The response of the patients according to combination of lacosamide with other drugs

\begin{tabular}{|c|c|c|c|c|c|}
\hline Characteristic & $n=115$ & Seizure free & $\begin{array}{l}\geq 50 \% \\
\text { reduction }\end{array}$ & $\begin{array}{l}<50 \% \\
\text { reduction }\end{array}$ & $\begin{array}{l}\text { Non } \\
\text { responder }\end{array}$ \\
\hline $\begin{array}{l}\text { Taking additional sodium channel } \\
\text { blocker drugs, n (\%) }\end{array}$ & $84(73.1)$ & $15(13.1)$ & $35(30.4)$ & $24(20.0)$ & $12(10.4)$ \\
\hline Taking other add-on drugs, n (\%) & $31(26.9)$ & $8(6.9)$ & $14(12.2)$ & $5(4.3)$ & $7(6.1)$ \\
\hline
\end{tabular}

Table 3. Side effects associated with lacosamide therapy

\begin{tabular}{lcc}
\hline Side effect & \multicolumn{2}{c}{ Total $(\mathrm{n}=22)$} \\
\cline { 2 - 3 } & $\mathrm{n}$ & $\%$ \\
\hline Sedation & 7 & 31.9 \\
Dizziness & 5 & 22.7 \\
Double or blurred vision & 4 & 18.2 \\
Nause & 2 & 9.1 \\
Headache & 2 & 9.1 \\
Balance disorder & 1 & 4.5 \\
Tremor & 1 & 4.5 \\
\hline
\end{tabular}

patients who did not respond to treatment, 8 (17.8\%) had genetic etiology, 12 (26.7\%) had unknown etiology, and 25 (55.5\%) had structural/metabolic etiology (Table 1).

Of 19 patients who used LCM as first add-on AED, 17 responded to treatment. When LCM was second add-on therapy, 28 of 32 patients responded. As third and fourth addon therapy, response rate was $18 \%$ and $7 \%$, respectively.

\section{Concomitant sodium channel blocking antiepileptic drugs}

Total of 115 patients were included in the present study. Results were grouped according to the type of concomitant AED: first group was sodium channel blocker (SCB) AEDs and second group was non-sodium channel blockers (NSCB). Results of the 2 groups were compared.

Most frequent AED used in addition to LCM was LEV, used by $45.4 \%$ of the patients. The other AEDs used were: OXC (26.2\%), CBZ (17.7\%), VPA (13.1\%), ZNS (7.3\%), PGB (6.5\%), LTG (6.4\%), TPM (5.8\%), CLB (5.2\%), PB (4.9\%), and PHT (4.6\%). Of the 115 patients, 84 were taking at least $1 \mathrm{SCB}$ (PHT, CBZ, OXZ or LTG) drug (Table 2).

Response rate in 84 patients using SCB and LCM combination was $59.5 \%(n=50)$ and was $70.9 \%$ in 31 patients receiving NSCB and LCM combination. The response rate was significantly higher in patients who used NSCB and LCM combination therapy $(p=0.032)$ (Table 2$)$.

\section{Safety and tolerability}

Adverse effects were reported by patients in 22 cases (15.4\%) following treatment with LCM. In 8 of these cases, effects were initial and transient; in 6 cases, effects disappeared or were tolerated by lowering the LCM dose, and in 8 cases, effects required cessation of LCM. Mean dose of LCM in the 22 patients who experienced an adverse effect was $310.6 \mathrm{mg} /$ day, compared with $322.4 \mathrm{mg} /$ day in the 106 patients who did not experience any adverse effects. No statistically significant difference was seen between these 2 doses $(p=0.304)$.

Most frequently seen adverse events were sedation in 7 patients, dizziness in 5, double or blurred vision in 4, nausea in 2 , headache in 2 , balance disorder in 1 , and tremor in 1 (Table 3).

\section{Discussion}

LCM stabilizes hyperactive neuronal membranes by selectively enhancing slow inactivation of neuronal voltage-gated sodium channels without affecting fast inactivation. An interaction with CRMP-2, which has been shown to enhance axonal outgrowth and might also be involved in the induction of other cellular responses, was initially identified as a second possible mechanism of action for LCM. LCM and its metabolites are eliminated by renal excretion. In adults with linear pharmacokinetics, the drug is $100 \%$ bioavailable when used orally and has low protein binding affinity $(<15 \%)$. LCM is metabolized in the liver, and the plasma halflife is approximately 13 hours. No drug-drug interactions have been reported. ${ }^{[11-14]}$

In a study conducted by Menachem that included 418 patients, LCM was found to be effective and result was statistically significant when compared with placebo control group at 400 to $600 \mathrm{mg} /$ day. There was no difference in the $200 \mathrm{mg} /$ 
day group. ${ }^{[15]}$ In another study in which 485 patients who received LCM at either 200 or 400 mg/day were enrolled, statistically significant difference was found when compared with placebo group. ${ }^{[16]} \mathrm{A} 50 \%$ reduction in seizure frequency was obtained in $33 \%$ and $41 \%$ of the patients who received LCM at 200 or 600 mg/day, respectively. ${ }^{[17]}$ Maximum recommended dose of LCM was reported to be $400 \mathrm{mg} /$ day because similar central nervous system and gastrointestinal side effects were seen in both 400 and $600 \mathrm{mg} /$ day doses. ${ }^{[18]}$ Biton et al. demonstrated in a multicenter trial that LCM in dose of 200 to $600 \mathrm{mg} /$ day in patients with partial onset seizures was safe and effective. ${ }^{[19]}$ In our study, we started with $100 \mathrm{mg} /$ day LCM and increased the dose to maximum 600 $\mathrm{mg} /$ day when it was necessary (mean: $335 \pm 28.2 \mathrm{mg} /$ day).

In multicenter study performed by Waldman Zadeh et al., partial onset seizure patients with no response to AED therapy were administered LCM as first and concurrent add-on therapy. In all groups, 50\% of the patients were seizure-free. This result suggested that LCM is safe and efficient AED as add-on therapy. ${ }^{[20]}$

Villanueva et al. suggested that LCM could control seizures when it was used as first or second add-on drug during early phases of LCM add-on therapy. ${ }^{[21]}$ In our study, we observed that LCM was more effective when it was used as first or second adjunct drug than as third or fourth AED.

Rate of adverse effects of LCM has been reported as $49 \%$ by Flores, and as $52 \%$ in another trial. ${ }^{[22]}$ Other reported frequencies were lower. We found that adverse effects occurred in $9.6 \%$ of patients, which was lower than rate reported in majority of studies. In studies to date, most frequently reported adverse event was dizziness, followed by nausea and vomiting. ${ }^{[23,24]}$ In the present study, most commonly observed side effects were sedation and dizziness.

It has been observed that combination of AEDs with different mechanisms was more effective and tolerable than combination of AEDs with similar mechanisms. ${ }^{[25]}$ It has been reported that LCM was more effective when combined with NSCBs. ${ }^{[26]}$ Flores et al. reported that when LCM was combined with SCB AEDs, patients responded at a higher rate, although difference was not statistically significant. ${ }^{[22]}$ As a result, it is thought that combination of NSCB agents with LCM is more effective and tolerable, as we found in the present study.
Results of our study supported earlier research that partial onset seizures can be controlled with LCM. When patients were treated with 300 to 400 mg of LCM daily, significant reduction in seizure frequency, with some achieving seizurefree status, was observed.

It was interesting to find that the patients with genetic epilepsy did not respond to LCM, although the number of patients in that category was very small. It is worth mentioning that LCM was more effective in structural/metabolic etiology group (77.1\%).

\section{Conclusion}

Thus far, with regard to LCM effectiveness, in Turkey there had been only pre-market study conducted by Genç et al. of 14 patients diagnosed with refractory partial epilepsy. ${ }^{[14]}$ We think that the present study is critical as first in Turkey to examine LCM treatment effectiveness and safety in patients with focal seizures.

Our data in clinical setting suggest that LCM is an effective and well-tolerated AED for the treatment of focal onset seizures.

\section{Ethics committee approval}

Clinical Research Ethics Committee approved the study.

\section{Informed consent}

Written informed consent was obtained from the parents of the patients who participated in this study.

\section{Peer-review}

Externally peer-reviewed.

\section{Author contributions}

Concept: O.E, D.I.A; Design: O.E, D.I.A; Supervision: O.E; Resource: O.E, D.I.A; Materials: O.E, D.I.A, G.A.; Data Collection and/or Processing: D.I.A.; Analysis and/or Interpretation O.E..; Literature Search: O.E, D.I.A; Writing: O.E, D.I.A.; Critical Reviews: O.E, D.I.A, G.A.

\section{Financial disclosure}

No funding agency had any part in the study design, collection, analysis, and/or writing of this paper.

\section{Conlicft of interest}

The authors declare no competing interests. 


\section{References}

1. From the Centers for Disease Control and Prevention. Prevalence of self-reported epilepsy--United States, 1986-1990. JAMA 1994;272(24):1893. [CrossRef]

2. Chung S, Wang N, Hank N. Comparative retention rates and long-term tolerability of new antiepileptic drugs. Seizure 2007;16(4):296-304. [CrossRef]

3. Kwan P, Brodie MJ. Early identification of refractory epilepsy. N Engl J Med 2000;342(5):314-9. [CrossRef]

4. Perucca E, French J, Bialer M. Development of new antiepileptic drugs: challenges, incentives, and recent advances. Lancet Neurol 2007;6(9):793-804. [CrossRef]

5. Beydoun A, D'Souza J, Hebert D, Doty P. Lacosamide: pharmacology, mechanisms of action and pooled efficacy and safety data in partial-onset seizures. Expert Rev Neurother 2009;9(1):33-42. [CrossRef]

6. Chung SS. Lacosamide: new adjunctive treatment option for partial-onset seizures. Expert Opin Pharmacother 2010;11(9):1595-602. [CrossRef]

7. Velioglu SK, Bakirdemir M, Can G, Topbas M. Prevalence of epilepsy in northeast Turkey. Epileptic Disord 2010;12(1):22-37.

8. Celikkaş E, Erdinç OO, Metintas S, Fidan HS, Arikan I, Kalyoncu C, et al. Incidence of epilepsy in a defined area of Central Anatolia, Turkey, after 15 years of age. Neuroepidemiology 2010;35(3):221-5. [CrossRef]

9. VIMPAT (lacosamide). Summary of Product Characteristics. UCB; 2010.

10. Hoy SM. Lacosamide: a review of its use as adjunctive therapy in the management of partial-onset seizures. CNS Drugs 2013;27(12):1125-42. [CrossRef]

11. Berg AT, Millichap JJ. The 2010 revised classification of seizures and epilepsy. Continuum (Minneap Minn) 2013;19(3 Epilepsy):571-97.

12. Kelemen A, Halász P. Lacosamide for the prevention of partial onset seizures in epileptic adults. Neuropsychiatr Dis Treat 2010;6:465-71. [CrossRef]

13. Errington AC, Stöhr T, Heers C, Lees G. The investigational anticonvulsant lacosamide selectively enhances slow inactivation of voltage-gated sodium channels. Mol Pharmacol 2008;73(1):157-69. [CrossRef]

14. Genç F, Ucan FE, Akca G, Aydemir Y, Kutlu G, Erdal A, et al. The Effectivety, Safety and Tolerability Profile of Lacosamide Therapy in Refractory Epilepsy: Premarketing Experience. Epilepsi 2014; 20(3): 121-5 [CrossRef]

15. Ben-Menachem E, Biton V, Jatuzis D, Abou-Khalil B, Doty $P$,
Rudd GD. Efficacy and safety of oral lacosamide as adjunctive therapy in adults with partial-onset seizures. Epilepsia 2007;48(7):1308-17. [CrossRef]

16. Halász $P$, Kälviäinen $R$, Mazurkiewicz-Beldzińska $M$, Rosenow $F$, Doty $P$, Hebert $D$, et al. Adjunctive lacosamide for partial-onset seizures: Efficacy and safety results from a randomized controlled trial. Epilepsia 2009;50(3):443-53. [CrossRef]

17. Verrotti A, Loiacono G, Pizzolorusso A, Parisi P, Bruni O, Luchetti $A$, et al. Lacosamide in pediatric and adult patients: comparison of efficacy and safety. Seizure 2013;22(3):210-6. [CrossRef]

18. Ben-Menachem E. Lacosamide: an investigational drug for adjunctive treatment of partial-onset seizures. Drugs Today (Barc) 2008;44(1):35-40. [CrossRef]

19. Biton V, Gil-Nagel A, Isojarvi J, Doty P, Hebert D, Fountain NB. Safety and tolerability of lacosamide as adjunctive therapy for adults with partial-onset seizures: Analysis of data pooled from three randomized, double-blind, placebo-controlled clinical trials. Epilepsy Behav 2015;52(Pt A):119-27

20. Zadeh WW, Escartin A, Byrnes W, Tennigkeit F, Borghs S, Li T, et al. Efficacy and safety of lacosamide as first add-on or later adjunctive treatment for uncontrolled partial-onset seizures: A multicentre open-label trial. Seizure 2015;31:72-9. [CrossRef]

21. Villanueva V, Garcés $M$, López-Gomáriz $E$, Serratosa JM, González-Giráldez B, Parra J, et al. Early add-on lacosamide in a real-life setting: results of the REALLY study. Clin Drug Investig 2015;35(2):121-31. [CrossRef]

22. Flores L, Kemp S, Colbeck K, Moran N, Quirk J, Ramkolea P, et al. Clinical experience with oral lacosamide as adjunctive therapy in adult patients with uncontrolled epilepsy: a multicentre study in epilepsy clinics in the United Kingdom (UK). Seizure 2012;21(7):512-7 [CrossRef]

23. Wehner T, Bauer S, Hamer HM, Hattemer K, Immisch I, Knake $\mathrm{S}$, et al. Six months of postmarketing experience with adjunctive lacosamide in patients with pharmacoresistant focal epilepsy at a tertiary epilepsy center in Germany. Epilepsy Behav 2009;16(3):423-5. [CrossRef]

24. Bootsma HP, Ricker L, Hekster YA, Hulsman J, Lambrechts D, Majoie $M$, et al. The impact of side effects on long-term retention in three new antiepileptic drugs. Seizure 2009;18(5):327-31.

25. Harden CL, Cohn A, Lowe M, Serrano E. Initial post marketing experience with lacosamide in adult patients with epilepsy. Epilepsy Res 2012;98(2-3):260-3. [CrossRef]

26. Sake JK, Hebert D, Isojärvi J, Doty P, De Backer M, Davies K, et al. A pooled analysis of lacosamide clinical trial data grouped by mechanism of action of concomitant antiepileptic drugs. CNS Drugs 2010;24(12):1055-68. [CrossRef] 